\title{
Potential of duckweed (Lemna minor) for removal of nitrogen and phosphorus from water under salt stress
}

Chunguang Liu $^{\mathrm{a}, \mathrm{b}^{*}}$, Zheng Dai ${ }^{\mathrm{a}}$, Hongwen Sun ${ }^{\mathrm{a}}$

${ }^{\text {a }}$ Key Laboratory of Pollution Processes and Environmental Criteria (Ministry of Education), Nankai University, Tianjin 300350, China

${ }^{b}$ Tianjin Key Laboratory of Environmental Remediation and Pollution Control, Tianjin 300350, China

*Corresponding author

Address: College of Environmental Science and Engineering, Nankai University 38 Tongyan Rd., Tianjin 300350, China

Phone: + 8613920867366

Fax: + 862223501117

E-mail address: liuchunguang@nankai.edu.cn

E-mail of other authors:

Zheng Dai: daizhengnku@163.com

Hongwen Sun: sunhongwen@ nankai.edu.cn

\begin{abstract}
Duckweed plays a major role in the removal of nitrogen $(\mathrm{N})$ and phosphorus (P) from water. To determine the effect of salt stress on the removal of $\mathrm{N}$ and $\mathrm{P}$ by duckweed, we cultured Lemna minor, a common species of duckweed, in N and P-rich water with $\mathrm{NaCl}$ concentrations ranging from 0 to $100 \mathrm{mM}$ for $24 \mathrm{~h}$ and $72 \mathrm{~h}$,
\end{abstract}


respectively. The results show that the removal capacity of duckweed for $\mathrm{N}$ and $\mathrm{P}$ was reduced by salt stress. Higher salt stress with longer cultivation period exerts more injury to duckweed and greater inhibition of $\mathrm{N}$ and P removal. Severe salt stress (100 $\mathrm{mM} \mathrm{NaCl}$ ) induced duckweed to release $\mathrm{N}$ and $\mathrm{P}$ and even resulted in negative removal efficiencies. The results indicate that $L$. minor should be used to remove $\mathrm{N}$ and $\mathrm{P}$ from water with salinities below $75 \mathrm{mM} \mathrm{NaCl}$, or equivalent salt stress.

Keywords: duckweed, Lemna minor, nitrogen, phosphorus, salt stress

\section{Introduction}

Excess nutrient, primarily anthropogenic nitrogen $(\mathrm{N})$ and phosphorus $(\mathrm{P})$, is one of the major causes of eutrophication in waterbodies. The need to reduce anthropogenic nutrients into aquatic ecosystems to prevent water eutrophication has been widely recognized (Conley et al., 2009). As an eco-friendly method, cultivation of aquatic macrophytes is attractive for nutrient removal and the restoration of eutrophic waterbodies (Dhote and Dixit, 2009).

Compared to other aquatic plants, duckweed proliferates rapidly and has an excellent capacity for nutrient uptake (Xu \& Shen, 2011). Additionally, duckweed is able to grow under a variety of climatic conditions and is easier to harvest than other macrophytes (Zirschky and Reed, 1988). Containing high content of protein, fat, amino acid, and starch, the harvested duckweed can be used for the production of animal feeds, fertilizer, and bioenergy products (Mbagwu and Adeniji, 1988; Soda et al., 2015). Due to these advantages, duckweed is considered to be a promising candidate for the remediation of eutrophic water.

In addition to $\mathrm{N}$ and $\mathrm{P}$, salt (mainly sodium chloride) is often brought into 
waterbodies by anthropogenic activities such as agricultural run-off, industrial and domestic discharge (Wang et al., 2008; Kaushal, 2016). It has been reported that salt stress induced oxidative damages and inhibition of photosynthesis (Oukarroum et al., 2015) in duckweed. Salt stress was also observed to influence the removal of contaminants by duckweed. For example, the effects of salt stress on the removal of technetium (Hattink et al., 2001), chromium (Boonyapookana et al., 2002), nickel (Yilmaz, 2007), and cadmium (Leblebici et al., 2011) by duckweed have already been demonstrated.

According to our investigation, in some rivers and lakes of coastal areas of China, salinities of water often exceed $3000 \mathrm{mg} / \mathrm{L}$ (unpublished data). Wendeou et al. (2013) studied the influence of salinity (up to $2276 \mathrm{mg} / \mathrm{L}$ ) on the removal of $\mathrm{N}$ and $\mathrm{P}$. Unfortunately, few studies have been conducted on the removal of $\mathrm{N}$ and $\mathrm{P}$ by duckweed under higher salinities. Furthermore, the responses of $\mathrm{N}$ and $\mathrm{P}$ removal and the growth of duckweed to durations of salt stress have not been recorded. The purpose of this study was to evaluate the potential of duckweed (Lemna minor) in removing $\mathrm{N}$ and $\mathrm{P}$ from water under different levels and durations of salt stress using a laboratory-scale batch experiment.

\section{Materials and methods}

\subsection{Plant cultivation}

Duckweed (L. minor) colonies were collected from Xiqing Lake in Tianjin, China, and were cultured in sterile 1/4 strength Hoagland's solution in a culture room at $25 \pm$ $2{ }^{\circ} \mathrm{C}$ with an irradiance of $72 \mu \mathrm{mol} / \mathrm{m}^{2} / \mathrm{s}$ supplied with a 16 -h photoperiod.

\subsection{Experimental design}

Approximately $0.5 \mathrm{~g}$ of duckweed colonies were transferred to $150 \mathrm{~mL}$ flask 
containing $100 \mathrm{~mL}$ of modified 1/4 Hoagland's solution. The modified solution contained $5 \mathrm{mg} \mathrm{N} / \mathrm{L}$ (supplied with $\mathrm{Ca}\left(\mathrm{NO}_{3}\right)_{2}$ and $\mathrm{KNO}_{3}$ ) and $0.5 \mathrm{mg} \mathrm{P} / \mathrm{L}$ (supplied with $\left.\mathrm{KH}_{2} \mathrm{PO}_{4}\right) . \mathrm{NaCl}$ was added to the solution to obtain the following concentrations: 0,25 , 50,75 , and $100 \mathrm{mM}$. Two batches of cultivation were conducted in different durations: $24 \mathrm{~h}$ and $72 \mathrm{~h}$. Each treatment was replicated four times. At the end of the cultivation, duckweed was harvested to obtain fresh weight (FW). Part of the fresh samples was used to determine chlorophyll and permeability of plasma membrane. Water samples were collected for $\mathrm{N}$ and $\mathrm{P}$ determination. Part of duckweed samples were dried and then ground into powder for total Kjeldahl nitrogen (TKN) and total phosphorus (TP) determination.

\subsection{Analytical methods}

Water samples were digested with alkaline potassium persulfate in an autoclave at $108 \mathrm{kPa}$, followed by spectrophotometric determination for total nitrogen (TN) and total phosphorus (TP). Water samples were filtered through $0.45 \mu \mathrm{m}$ membrane and then determined ammonia nitrogen $\left(\mathrm{NH}_{4}^{+}\right)$, nitrate nitrogen $\left(\mathrm{NO}_{3}{ }^{-}\right)$, and dissolved orthophosphate $\left(\mathrm{PO}_{4}{ }^{3-}\right)$ using colorimetric method. Chemical oxygen demand (COD) of water was determined using the Hach test kits with a UV-vis Spectrophotometer (DR 1010, Hach Company, Loveland, CO, USA). These water quality parameters were determined following Standard Methods (APHA et al., 2007). Total Kjeldahl nitrogen (TKN) of duckweed tissue was determined using a Kjeldahl nitrogen analyzer (Kjeltec 8400, Foss Analyzer, Höganäs, Sweden). Total phosphorus (TP) of duckweed samples were determined by molybdovanadate procedure after digesting with concentrated $\mathrm{H}_{2} \mathrm{SO}_{4}$ and $30 \% \mathrm{H}_{2} \mathrm{O}_{2}$ (Thomas et al., 1967).

Total chlorophyll was determined according to Huang et al. (2007). Fresh duckweed 
$(0.2 \mathrm{~g})$ was soaked in $10 \mathrm{~mL}$ of $95 \%(\mathrm{v} / \mathrm{v})$ alcohol for 3 days at room temperature in dark. The samples were centrifuged at $2790 \times g$ for $10 \mathrm{~min}$ and the absorbance of the supernatant was determined at 663 and $645 \mathrm{~nm}$. The concentrations of chlorophyll were calculated according to:

$C_{a}=12.72 A_{663}-2.69 A_{645}$

$C_{b}=22.90 A_{645}-4.68 A_{663}$

$C_{c h l}=C_{a}+C_{b}$

where $C_{a}, C_{b}$, and $C_{c h l}$ represent the content of chlorophyll $a$, chlorophyll $b$, and total chlorophyll, respectively; $A_{663}$ and $A_{645}$ are the absorbance at 663 and $645 \mathrm{~nm}$, respectively.

Plasma membrane permeability of duckweed was indicated by percent leakage of electrolyte, which was determined by measuring electrical conductivity (EC) of incubating medium according to Yan et al. (1996). Fresh duckweed (0.2 g) was soaked in deionized water at $30^{\circ} \mathrm{C}$ for $3 \mathrm{~h}$, and then the EC of water was measured. After the samples were boiled for 2 min and then cooled to $30^{\circ} \mathrm{C}$, the ECs were measured again. The percentage of electrolyte leakage was calculated using the following equation: $E C(\%)=\left(C_{1} / C_{2}\right) \times 100$

where $C_{1}$ and $C_{2}$ are the electrolyte conductivities measured before and after boiling, respectively.

The bioconcentration factor $(\mathrm{BCF})$ of $\mathrm{N}$ and $\mathrm{P}$ was calculated as $B C F=C_{p} / C_{w}$

where $C_{p}$ and $C_{w}$ are the nutrient concentrations in plant tissue and water, respectively. A larger BCF value implies greater phytoaccumulation capability.

\subsection{Statistics}


All data were performed by analysis of variance (ANOVA) and the differences were compared by employing the Duncan's test with a significance of $P<0.05$ using SPSS 20.0 (IBM Corp., Armonk, NY, USA).

\section{Results and discussion}

\subsection{Removal of nitrogen}

Duckweed was able to remove $\mathrm{NO}_{3}{ }^{-}$and the removal was inhibited by high levels of salt stress. At lower salt stress, duckweed with longer cultivation removed more $\mathrm{NO}_{3}{ }^{-}$. At $\mathrm{NaCl}$ concentrations ranging from 0 to $75 \mathrm{mM}, \mathrm{NO}_{3}{ }^{-}$concentrations decreased markedly compared to the initial concentration ( $5 \mathrm{mg} / \mathrm{L}$ ) (Fig. 1A). As expected, after $72 \mathrm{~h}$ of cultivation, $\mathrm{NO}_{3}{ }^{-}$concentrations were much lower than those after $24 \mathrm{~h}$ of cultivation. Despite cultivation time, $\mathrm{NO}_{3}{ }^{-}$concentrations increased progressively with increasing $\mathrm{NaCl}$ concentrations. At $100 \mathrm{mM} \mathrm{NaCl}$, after $24 \mathrm{~h}$ and $72 \mathrm{~h}$ of cultivation, $\mathrm{NO}_{3}{ }^{-}$increased to 4.83 and $5.87 \mathrm{mg} / \mathrm{L}$, respectively, indicating little to no $\mathrm{NO}_{3}{ }^{-}$removal by duckweed. 
(A)

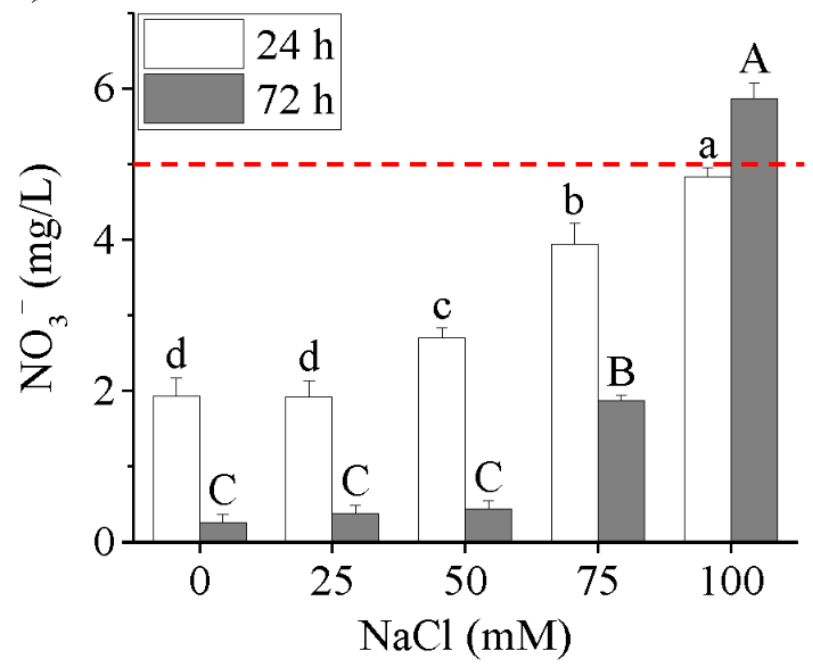

(B)

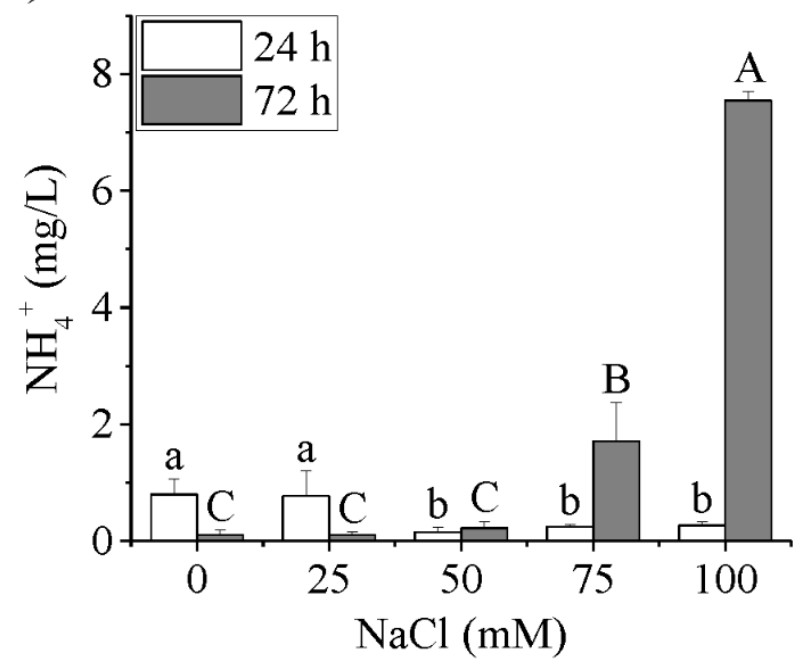

(C)

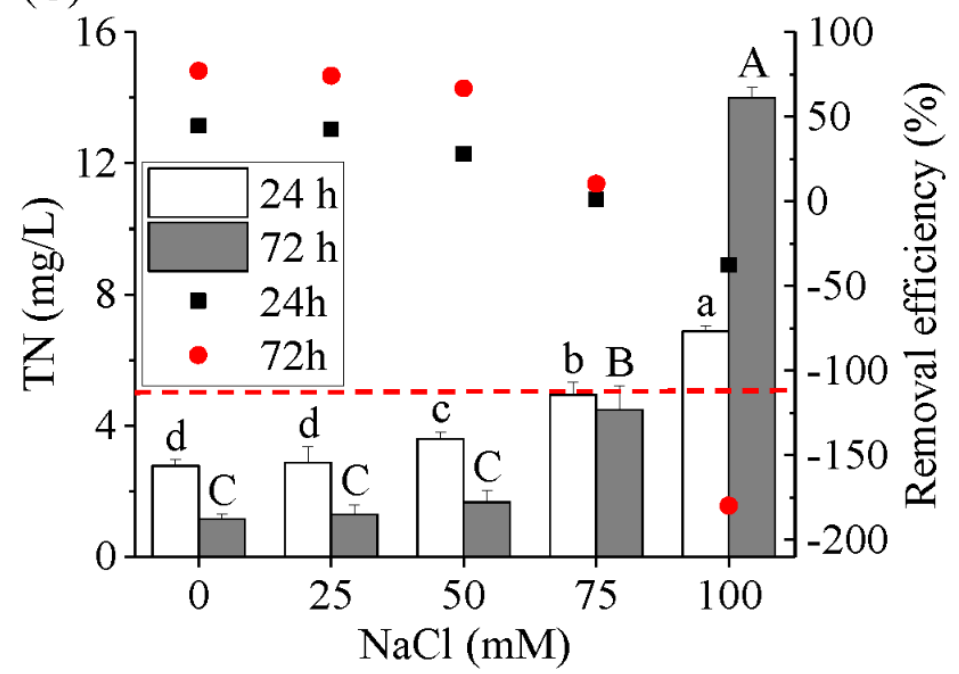

Fig.1. Effect of $\mathrm{NaCl}$ on the removal of $\mathrm{N}$ from water by duckweed: (A) Nitrate nitrogen 
concentration; (B) Ammonia nitrogen concentration; (C) Total nitrogen concentration and removal efficiency of TN. Dash line indicates the initial concentration of N. Values represent average of 4 replicates and error bars represent SE. Means with different letters are significantly different $(P<0.05)$. Lowercase and uppercase letters are for the data of $24 \mathrm{~h}$ and $72 \mathrm{~h}$ of cultivation, respectively. 
Nitrate nitrogen uptake may be reduced by the inhibition of duckweed growth and accompanied $\mathrm{NO}_{3}{ }^{-}$demand under salt stress, which is to be discussed in the later section. High concentrations of chloride $\left(\mathrm{Cl}^{-}\right)$may compete with $\mathrm{NO}_{3}{ }^{-}$directly for the binding sites of the transporter (Cerezo et al., 1997), which is a possible reason for the inhibition. Moreover, the inhibition of nitrate reductase induced by salt stress may cause an over accumulation of $\mathrm{NO}_{3}{ }^{-}$and subsequently an increase in efflux, which even results in the increase in $\mathrm{NO}_{3}{ }^{-}$concentrations (Ingemarsson et al., 1987). The increase in $\mathrm{NO}_{3}{ }^{-}$under severe salt stress $(100 \mathrm{mM} \mathrm{NaCl})$ is mainly due to the decomposition of duckweed, which in turn resulted in nitrification, adding $\mathrm{NO}_{3}{ }^{-}$to the medium (Suppadit, 2011).

Although $\mathrm{NH}_{4}{ }^{+}$was not supplied, it was still present in the culture water, indicating the generation of $\mathrm{NH}_{4}{ }^{+}$by duckweed. Higher salt stress and longer exposure induced more $\mathrm{NH}_{4}{ }^{+}$generation (Fig. 1B). At lower $\mathrm{NaCl}$ concentrations, the generation of $\mathrm{NH}_{4}{ }^{+}$ was mainly due to the degradation of nitrogenous organic matters which were exuded from the duckweed roots. Although duckweed had a higher affinity for $\mathrm{NH}_{4}{ }^{+}$than for $\mathrm{NO}_{3}{ }^{-}$(Cedergreen and Madsen, 2002), at lower $\mathrm{NaCl}$ concentrations ( 0 and $25 \mathrm{mM}$ ), duckweed grew well and took up more $\mathrm{NO}_{3}{ }^{-}$because of the high external $\mathrm{NO}_{3}{ }^{-}$ concentrations (Ingemarsson et al., 1987). After $72 \mathrm{~h}$ of cultivation, $\mathrm{NH}_{4}{ }^{+}$ concentrations at 75 and $100 \mathrm{mM} \mathrm{NaCl}$ increased significantly $(P<0.05)$ and reached 1.71 and $7.54 \mathrm{mg} / \mathrm{L}$, respectively. This was mainly attributed to the breakdown of duckweed tissue, which was degraded by bacteria and exoenzymes, and eventually released $\mathrm{NH}_{4}^{+}$.

Total nitrogen mainly includes $\mathrm{NO}_{3}{ }^{-}, \mathrm{NH}_{4}{ }^{+}$, and organic-N, and thus, the decline of TN means substantial removal of $\mathrm{N}$ from water. Similarly to $\mathrm{NO}_{3}{ }^{-}$and $\mathrm{NH}_{4}{ }^{+}$, the 
removal of TN was inhibited by salt stress. At 0,25 , and $50 \mathrm{mM} \mathrm{NaCl}$, TN decreased substantially compared to the initial concentration $\left(5 \mathrm{mg} / \mathrm{L}\right.$ in the form of $\left.\mathrm{NO}_{3}{ }^{-}\right)$, regardless of cultivation duration (Fig. 1C). As expected, after $72 \mathrm{~h}$ of cultivation, TN showed more decrease than that after $24 \mathrm{~h}$ of cultivation. The concentrations of TN increased with increasing $\mathrm{NaCl}$ concentrations eventually exceeded the initial concentration ( $5 \mathrm{mg} / \mathrm{L})$. At $100 \mathrm{mM} \mathrm{NaCl}$, after $72 \mathrm{~h}$ of cultivation, TN was much higher than that after $24 \mathrm{~h}$ of cultivation. According to plant element determination, the initial colonies of duckweed contained $50.7 \mathrm{mg}$ TKN/g DW, indicating that duckweed colonies had accumulated excessive $\mathrm{N}$ before transferring. According to Bonomo et al. (1997), duckweed was able to excessively accumulate $\mathrm{N}$ to the range of $20-60 \mathrm{mg} / \mathrm{g}$ DW under N-rich conditions. Mass balance calculations of $\mathrm{N}$ suggested that more than $11.3 \%$ and $54.5 \%$ of $\mathrm{N}$ were released from duckweeds which were cultured at $100 \mathrm{mM}$ $\mathrm{NaCl}$ for $24 \mathrm{~h}$ and $72 \mathrm{~h}$, respectively. This results suggest that the dramatic increase in $\mathrm{TN}$ at $100 \mathrm{mM} \mathrm{NaCl}$ may have been due to the release of over-accumulated $\mathrm{N}$ in duckweed.

To directly evaluate the potential for duckweed in the removal of $\mathrm{N}$ under salt stress, the removal efficiencies of $\mathrm{TN}$ were calculated. With increasing $\mathrm{NaCl}$ concentrations, $\mathrm{TN}$ removal decreased progressively (Fig. 1C). At $\mathrm{NaCl}$ concentrations ranging from 0 to $75 \mathrm{mM}$, TN removal efficiencies after $72 \mathrm{~h}$ of cultivation were higher than those after $24 \mathrm{~h}$ of cultivation. At $100 \mathrm{mM} \mathrm{NaCl}$, regardless of $24 \mathrm{~h}$ or $72 \mathrm{~h}$ of cultivation, TN removal efficiencies decreased to negative values. The removal efficiencies of TN decreased to $-37.5 \%$ and $-180 \%$ after $24 \mathrm{~h}$ and $72 \mathrm{~h}$ cultivation, respectively. These results suggest that L. minor should be used to remove $\mathrm{N}$ under salt stress lower than 75 $\mathrm{mM} \mathrm{NaCl}$ or equivalent salinities. 
Bioconcentration factor $(\mathrm{BCF})$ indicates the capacity of a plant to accumulate a substance in the tissue from the medium (generally water) which it is exposed. To evaluate the capacity of duckweed for $\mathrm{N}$ accumulation, $\mathrm{BCF}$ values were calculated (Table 1). The BCF values of $\mathrm{N}$ decreased gradually with increasing $\mathrm{NaCl}$ concentrations. The BCF values of $72 \mathrm{~h}$ cultivation were greater than those of $24 \mathrm{~h}$ cultivation, except when $\mathrm{NaCl}$ reached $100 \mathrm{mM}$. These results demonstrate that the accumulation of $\mathrm{N}$ for duckweed is inhibited by salt stress.

Table 1 Bioconcentration factor $(\mathrm{BCF})$ of duckweed for $\mathrm{N}$ and $\mathrm{P}$.

\begin{tabular}{rrrrrr}
\hline \multirow{2}{*}{\begin{tabular}{r}
$\mathrm{NaCl}$ \\
\cline { 5 - 6 } \cline { 5 - 6 } \cline { 5 - 6 }
\end{tabular}} & \multicolumn{2}{c}{$\mathrm{BCF}_{\mathrm{N}}\left(\times 10^{4}\right)$} & & \multicolumn{2}{c}{$\mathrm{BCF}_{\mathrm{P}}\left(\times 10^{4}\right)$} \\
\hline 0 & $1.84 \pm 0.13 \mathrm{a}$ & $4.48 \pm 0.59 \mathrm{a}$ & & $6.73 \pm 0.56 \mathrm{~b}$ & $88.28 \pm 45.19 \mathrm{~b}$ \\
25 & $1.80 \pm 0.28 \mathrm{a}$ & $4.07 \pm 0.86 \mathrm{ab}$ & & $8.06 \pm 1.62 \mathrm{a}$ & $151.69 \pm 25.69 \mathrm{a}$ \\
50 & $1.41 \pm 0.08 \mathrm{~b}$ & $3.16 \pm 0.47 \mathrm{~b}$ & & $7.71 \pm 0.63 \mathrm{ab}$ & $83.51 \pm 42.46 \mathrm{~b}$ \\
75 & $1.03 \pm 0.08 \mathrm{c}$ & $1.15 \pm 0.20 \mathrm{c}$ & & $2.79 \pm 0.39 \mathrm{c}$ & $11.03 \pm 1.96 \mathrm{c}$ \\
100 & $0.74 \pm 0.02 \mathrm{~d}$ & $0.36 \pm 0.01 \mathrm{c}$ & & $1.21 \pm 0.05 \mathrm{~d}$ & $0.58 \pm 0.04 \mathrm{c}$ \\
\hline
\end{tabular}

$\mathrm{BCF}_{\mathrm{N}}$ and $\mathrm{BCF}_{\mathrm{P}}$ represent the $\mathrm{BCF}$ of duckweed for $\mathrm{N}$ and $\mathrm{P}$, respectively. The values represent mean of 4 replicates \pm standard deviation. Means followed by the same letter in the same column are not different significantly according to Duncan's multiple comparison test at a level of $P<0.05$.

\subsection{Removal of phosphorus}

Duckweed reduced $\mathrm{P}$ concentrations, but the removal was inhibited under higher salt stress. Additionally, longer cultivation showed a much better performance in P removal. Orthophosphate and TP showed similar values and tendencies, indicating $\mathrm{PO}_{4}{ }^{3-}$ was the main component of $\mathrm{TP}$ (Fig. 2A, B). At $\mathrm{NaCl}$ concentrations ranging from 0 to $50 \mathrm{mM}$, compared with the initial $\mathrm{P}$ concentration $(0.5 \mathrm{mg} / \mathrm{L})$, the concentrations of $\mathrm{PO}_{4}{ }^{3-}$ and TP both decreased. The decrease after $72 \mathrm{~h}$ of cultivation was much more than that after $24 \mathrm{~h}$ of cultivation. At $75 \mathrm{mM} \mathrm{NaCl}$, both $\mathrm{PO}_{4}{ }^{3-}$ and TP concentrations after $24 \mathrm{~h}$ of cultivation increased significantly $(P<0.05)$ and exceeded the initial concentration. At 
$100 \mathrm{mM} \mathrm{NaCl}, \mathrm{PO}_{4}{ }^{3-}$ and TP increased to much higher levels, and their concentrations after $72 \mathrm{~h}$ of cultivation even exceeded those after $24 \mathrm{~h}$ of cultivation. Plant element determination showed the initial P of duckweed was $21.3 \mathrm{mg} / \mathrm{g} \mathrm{DW}$, which was in the range of $\mathrm{P}$ contents previously recorded as $2-29 \mathrm{mg} / \mathrm{g} \mathrm{DW}$ in P-rich water (Bonomo et al., 1997). According to mass balance calculation of $\mathrm{P}$, more than $18.2 \%$ and $45.7 \%$ of $\mathrm{P}$ were released from duckweed cultured in $100 \mathrm{mM}$ for $24 \mathrm{~h}$ and $72 \mathrm{~h}$, respectively. These results suggest that considerable amounts of phosphorus stored in duckweed will be released under severe salt stress.

(A)
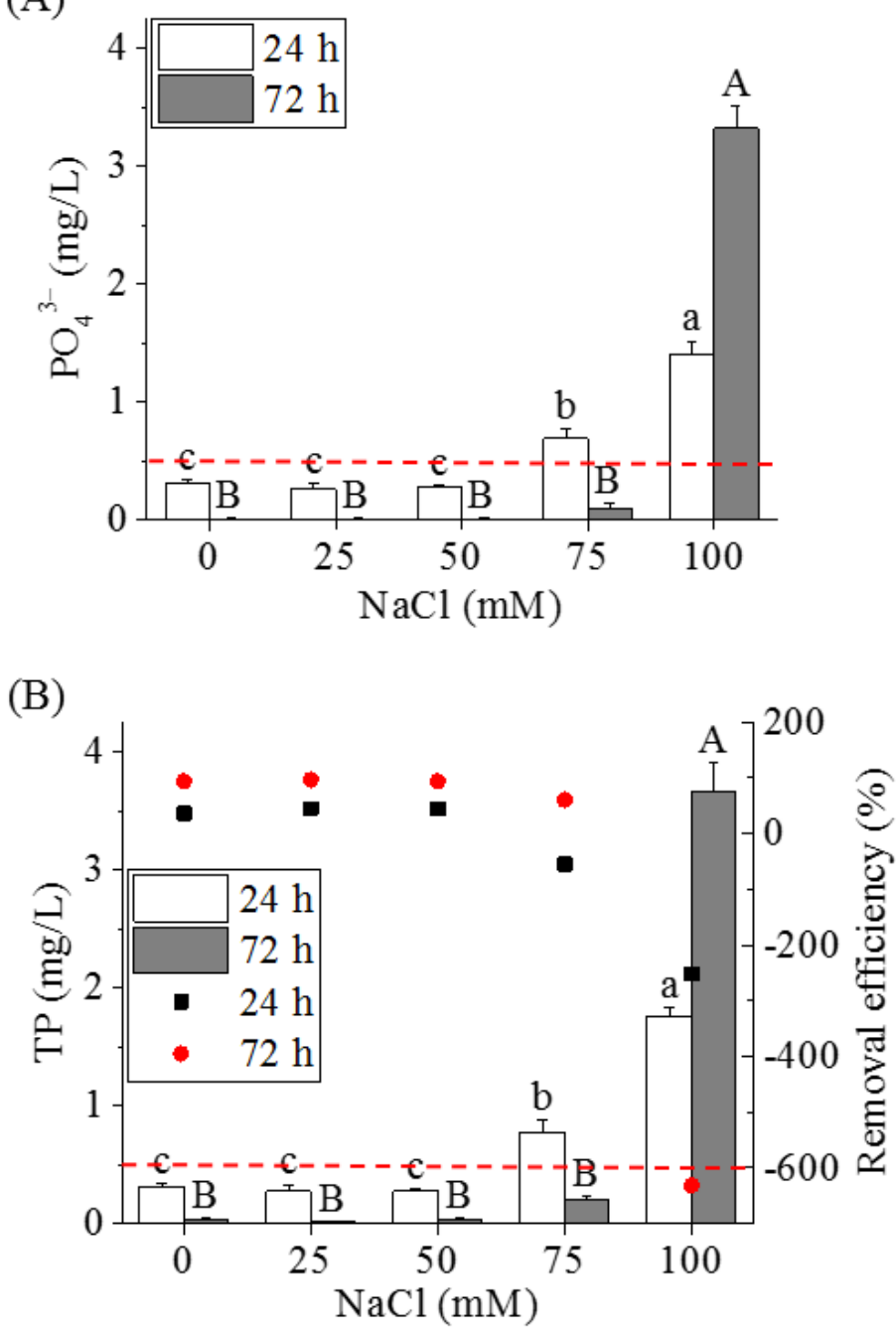

Fig. 2. Effect of $\mathrm{NaCl}$ on the removal of $\mathrm{P}$ from water by duckweed: (A) Orthophosphate 
concentration; (B) Total phosphorus concentration and removal efficiency of TP. Dash line indicates the initial concentration of P. Means with different letters are significantly different $(P<0.05)$. Lowercase and uppercase letters are for the data of $24 \mathrm{~h}$ and $72 \mathrm{~h}$ of cultivation, respectively.

Removal efficiencies of TP were calculated and shown in Fig. 2B. With $\mathrm{NaCl}$ concentrations varying from 0 to $50 \mathrm{mM}$, removal efficiencies of TP after $72 \mathrm{~h}$ of cultivation were much higher than those after $24 \mathrm{~h}$ of cultivation. At $75 \mathrm{mM} \mathrm{NaCl}$, TP removal efficiencies after both terms of cultivation decreased markedly, and those after $24 \mathrm{~h}$ of cultivation even decreased to negative level (-54.9\%). At $100 \mathrm{mM} \mathrm{NaCl}, \mathrm{TP}$ removal efficiencies after $24 \mathrm{~h}$ of cultivation decreased to $-251 \%$, and those after $72 \mathrm{~h}$ of cultivation even sharply decreased to $-631.6 \%$. These results suggest that long-term cultivation at extremely high concentrations of $\mathrm{NaCl}$ (e.g., $100 \mathrm{mM}$ ) caused dramatic reduction in P removal efficiencies even to negative values.

It has been observed that $\mathrm{P}$ uptake by freshwater aquatic plant was inhibited by salt stress in previous studies. For example, $\mathrm{P}$ uptake has been recorded to decrease significantly in Hydrilla verticillata, Myriophyllum spicatum, and Vallisneria americana under salinity of 6\%o $(\sim 103 \mathrm{mM} \mathrm{NaCl}), 12 \%$ o ( 205 mM NaCl), and 12\%o, respectively (Twilley and Barko, 1990). Even for salt-tolerant marine algae (e.g., Ulva pertusa), P uptake has also been observed to decrease when salinity exceeds $25 \mathrm{psu}(\sim 428 \mathrm{mM}$ $\mathrm{NaCl}$ ) (Choi et al., 2010). An explanation for the inhibition in $\mathrm{P}$ uptake is the decrease in plant growth and P demand that was induced by salt stress. Another possible explanation is the competition between chloride $\left(\mathrm{Cl}^{-}\right)$and $\mathrm{PO}_{4}{ }^{3-}$ for the transport site of cell-surface (Navarro et al., 2001). Besides plant uptake, P was also removed by adsorption onto the biofilms attached to duckweed and the container walls (Körner et al., 2003). The adsorption may also be influenced by water salinity, but the related mechanisms remain unclear. 
The BCF of $\mathrm{P}$ for duckweed was calculated and shown in Table 1. In both $24 \mathrm{~h}$ and $72 \mathrm{~h}$ cultivation, the $\mathrm{BCF}$ values of $\mathrm{P}$ increased at $25 \mathrm{mM} \mathrm{NaCl}$. The increase in $\mathrm{P}$ accumulation can be explained by the increase in internal P requirement (Awad et al., 1990). The $\mathrm{BCF}$ values of $\mathrm{P}$ began to decrease at $50 \mathrm{mM} \mathrm{NaCl}$, and decreased to an extreme low level at 75 and $100 \mathrm{mM} \mathrm{NaCl}$. These results demonstrate that $\mathrm{P}$ accumulation by duckweed is facilitated by slight salt stress but inhibited by severe salt stress.

\subsection{Organic compounds generation}

To investigate the content of organic compounds in water generated by duckweed, COD of water samples was determined. The data showed that COD was generated regardless of salt stress and cultivation time (Fig. 3A). The rapid generation of COD in water is mainly attributed to the release of dissolved organic matters of low molecular weights (<1000 Daltons) (Baker and Farr, 1987). The major components of the dissolved organic matters may be extracellular polymers, which are easily induced by environmental stresses (Babel et al., 2002). Therefore, COD increased progressively with increasing $\mathrm{NaCl}$ concentrations. Through the decomposition of organic compounds, nutrients (mainly N and P) release into the water (Szabó et al., 2000), resulting in the increase in $\mathrm{N}$ and $\mathrm{P}$. When the concentrations of TN and TP were plotted against COD, respectively, positive linear correlations were observed (Fig. 3B). Moreover, there is a high degree of correlation between TN and COD $\left(R^{2}=0.6755, P=0.000\right)$, as well as TP and $\operatorname{COD}\left(R^{2}=0.5697, P=0.000\right)$. These results suggest that the organic $\mathrm{N}$ and $\mathrm{P}$ induced by salt stress made a significant contribution to the increase in TN and TP. 


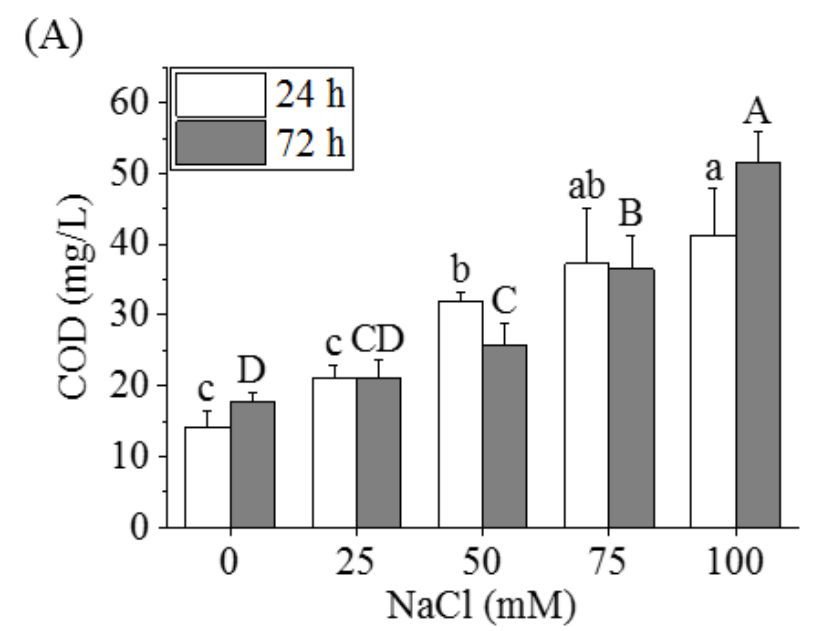

(B)

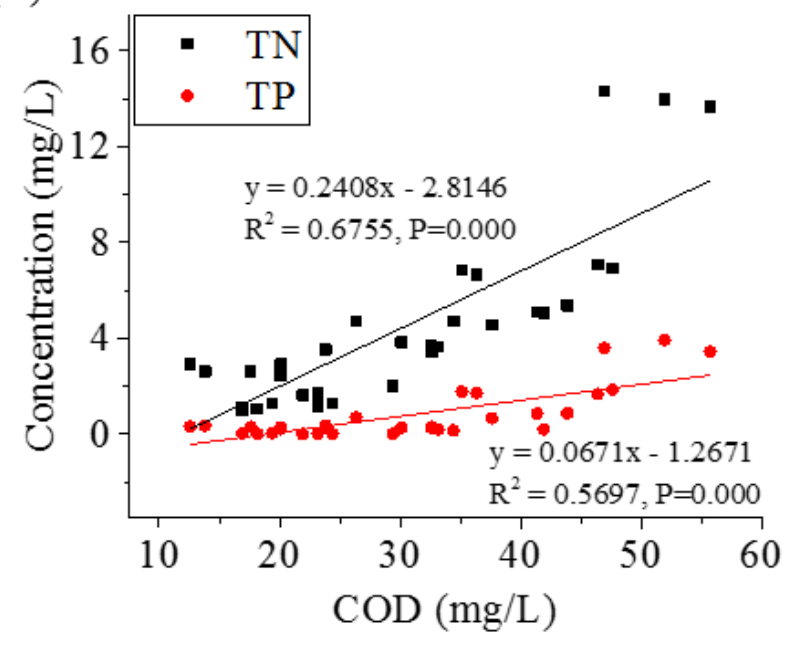

Fig. 3. Effect of $\mathrm{NaCl}$ on $\mathrm{COD}$ generation (A) and the relationship between concentration of $\mathrm{COD}$ and TP and TN, respectively (B). Means with different letters are significantly different $(P<0.05)$. Lowercase and uppercase letters are for the data of $24 \mathrm{~h}$ and $72 \mathrm{~h}$ of cultivation, respectively.

\subsection{Duckweed growth}

With increasing $\mathrm{NaCl}$ concentrations, the numbers of fronds of individual duckweed decreased, regardless of cultivation time (Fig. 4). In general, a healthy duckweed colony has 3 or 4 fronds. Previous studies have reported that salt stress can reduce the total number of duckweed frond (Chang et al., 2012; Wendeou et al., 2013). The decrease of frond number of individual duckweed observed in the present work was due to the fragile stipe caused by salt damage. Regardless of $\mathrm{NaCl}$ concentrations, after $24 \mathrm{~h}$ of 
cultivation, most fronds looked green and vigorous. In contrast, after $72 \mathrm{~h}$ of cultivation, most fronds at $50 \mathrm{mM}$ and higher $\mathrm{NaCl}$ concentrations exhibited partially transparent and chlorotic effect. At $100 \mathrm{mM} \mathrm{NaCl}$, the fronds were almost bleached after $72 \mathrm{~h}$ of cultivation. The signs of chlorosis were attributed to the loss of photosynthetic pigments, and these results were in agreement with the observations in previous studies (Chang et al., 2012; Cheng et al., 2013).
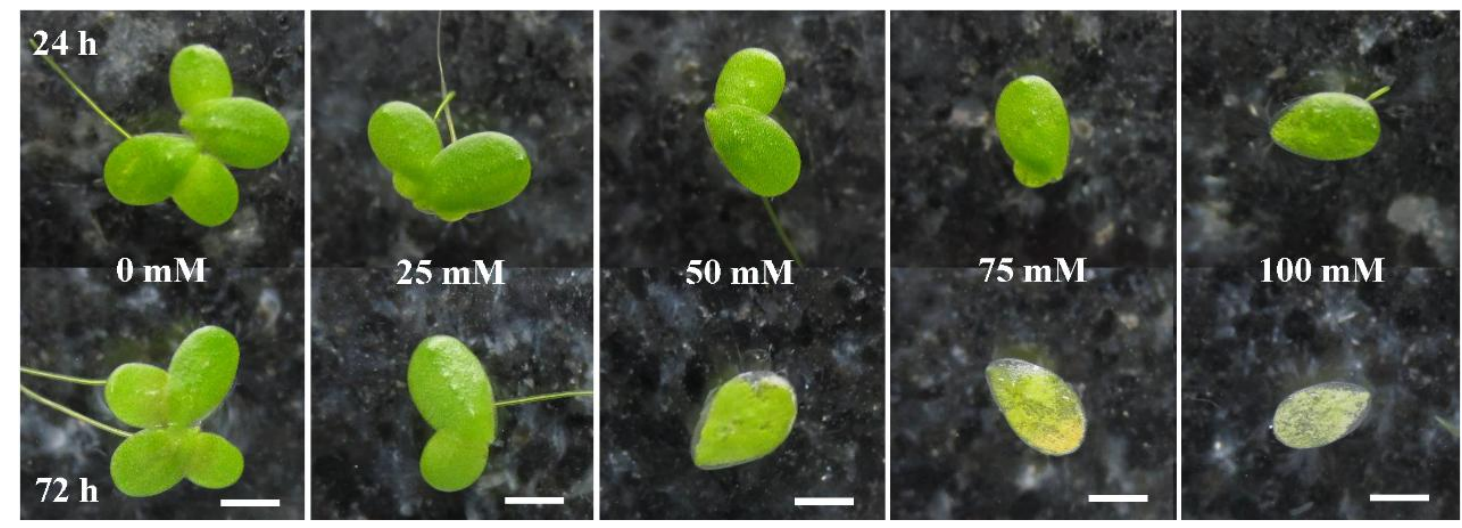

Fig. 4. Effect of $\mathrm{NaCl}$ on fronds of duckweed $(\mathrm{Bar}=2 \mathrm{~mm})$.

Chlorophyll content of duckweed decreased with increasing $\mathrm{NaCl}$ concentrations (Fig. 5A). This is in corresponding with the variation of frond color presented in Fig. 4. After $72 \mathrm{~h}$ of cultivation, chlorophyll contents of duckweed were much lower than those after $24 \mathrm{~h}$ of cultivation, which was due to the higher accumulative rates of frond biomass than those of chlorophyll contents. At $50 \mathrm{mM} \mathrm{NaCl}$ and higher concentrations, chlorophyll contents decreased significantly $(P<0.05)$, and the chlorophyll contents after $72 \mathrm{~h}$ cultivation decreased much more than those after $24 \mathrm{~h}$ of cultivation. The loss in pigment contents could be due to direct oxidative breakdown of pigments and/or the destruction of thylakoid pigment-protein complexes in photosynthetic reaction centers (Chang et al., 2012). Obviously, higher $\mathrm{NaCl}$ concentrations and longer exposure time exerted more damage to the synthesis of chlorophyll. 


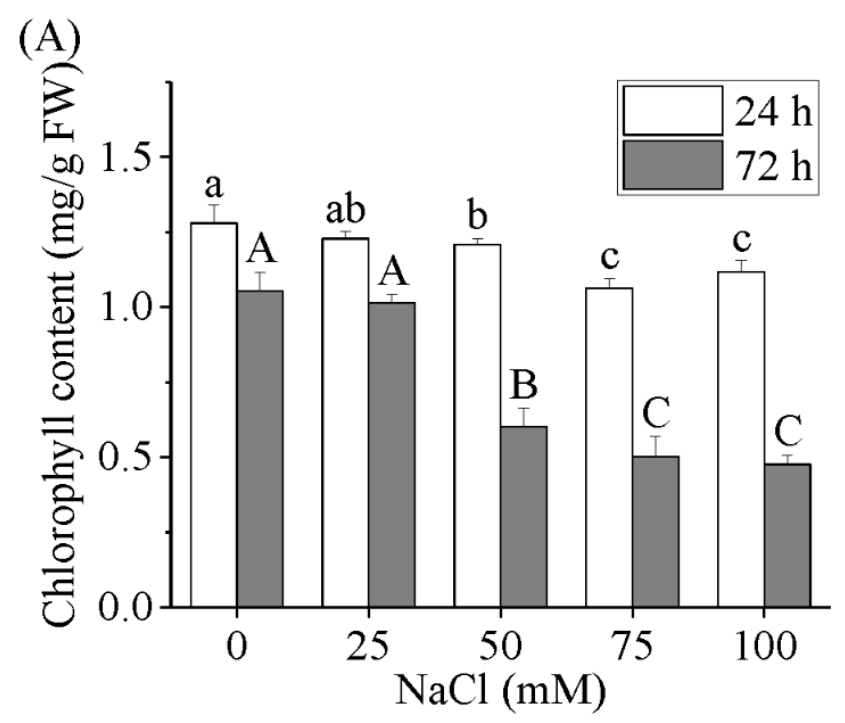

(B)

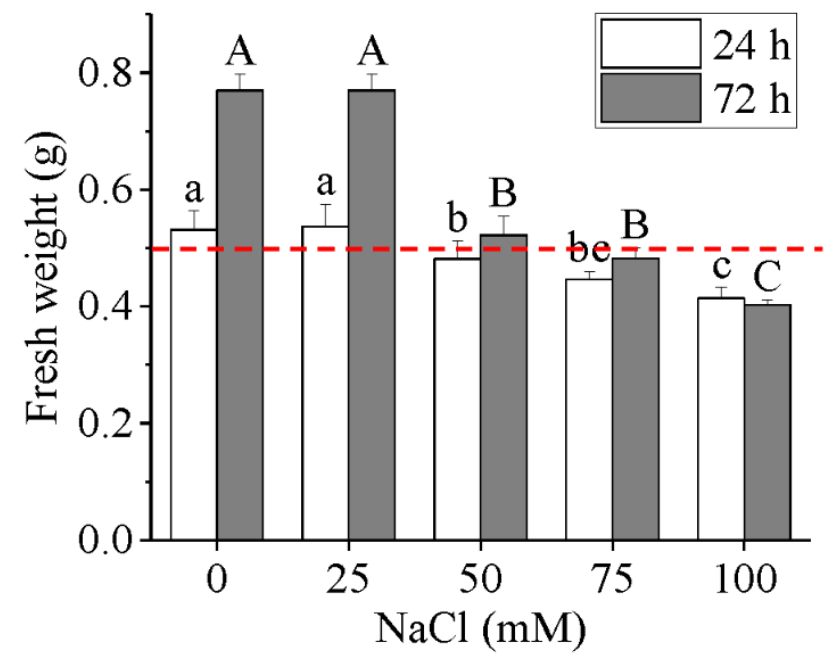

Fig. 5. Effect of $\mathrm{NaCl}$ on chlorophyll synthesis and biomass accumulation of duckweed: (A)

Chlorophyll content; (B) Fresh weight of duckweed (dash line indicates the initial FW of duckweed).

Means with different letters are significantly different $(P<0.05)$. Lowercase and uppercase letters are for the data of $24 \mathrm{~h}$ and $72 \mathrm{~h}$ of cultivation, respectively.

Fresh weight of duckweed decreased with increasing $\mathrm{NaCl}$ concentrations (Fig. 5B). Regardless of cultivation time, no inhibitive effect was observed on the growth of duckweed at $25 \mathrm{mM} \mathrm{NaCl}$. At $50 \mathrm{mM}$ and higher concentrations of $\mathrm{NaCl}$, duckweed FW decreased significantly $(P<0.05)$. The reduction of duckweed FW under high salinities is mainly attribute to: (1) the inhibition in biomass accumulation, including the 
restriction of root expansion and the reduction in frond number (Chang et al., 2012); (2) the breakdown of fronds and roots; and (3) the leakage of electrolyte.

As compared with the initial FW (0.5 g for each flask), duckweed FW showed almost no increase or negative increase at $50 \mathrm{mM} \mathrm{NaCl}$ and higher concentrations. This result suggests that duckweed has a lower tolerance to $\mathrm{NaCl}$ than that reported by Sikorski et al. (2013). In their study, duckweed (L. minor) showed a negative growth rate when $\mathrm{NaCl}$ exceeded $250 \mathrm{mM}$. The growth of other species of duckweed have also been reported to be inhibited by salt stress. For example, Spirodela polyrhiza showed negative relative growth rate at $100 \mathrm{mM}$ and higher salinities (Leblebici et al., 2011). Chang et al. (2012) reported that the growth of S. polyrhiza completely ceased at 200 $\mathrm{mM} \mathrm{NaCl}$. Lemna gibba showed negative growth when salinities exceeded $250 \mathrm{mM}$ (Yilmaz, 2007).

\subsection{Membrane permeability}

To investigate the damage of $\mathrm{NaCl}$ stress to the plasma membrane of duckweed, electrical conductivity (EC) of incubating medium of duckweed samples was determined (Fig. 6A). Electrical conductivity of incubating medium has been used as an index of membrane permeability of damaged plant tissue, which leaks electrolyte with charged inorganic or organic molecules (Bajji et al., 2002). The data show that EC increased progressively with increasing $\mathrm{NaCl}$ concentrations, indicating the membrane permeability of duckweed was dependent on salt stress. At 0 and $25 \mathrm{mM} \mathrm{NaCl}, \mathrm{EC}$ was present at the same level. At $50 \mathrm{mM}$ and higher concentrations of $\mathrm{NaCl}, \mathrm{EC}$ increased dramatically, especially for that after $72 \mathrm{~h}$ of cultivation. This result suggests that under higher salt stress, the damage to plasma membrane of duckweed was dependent on exposure time. 

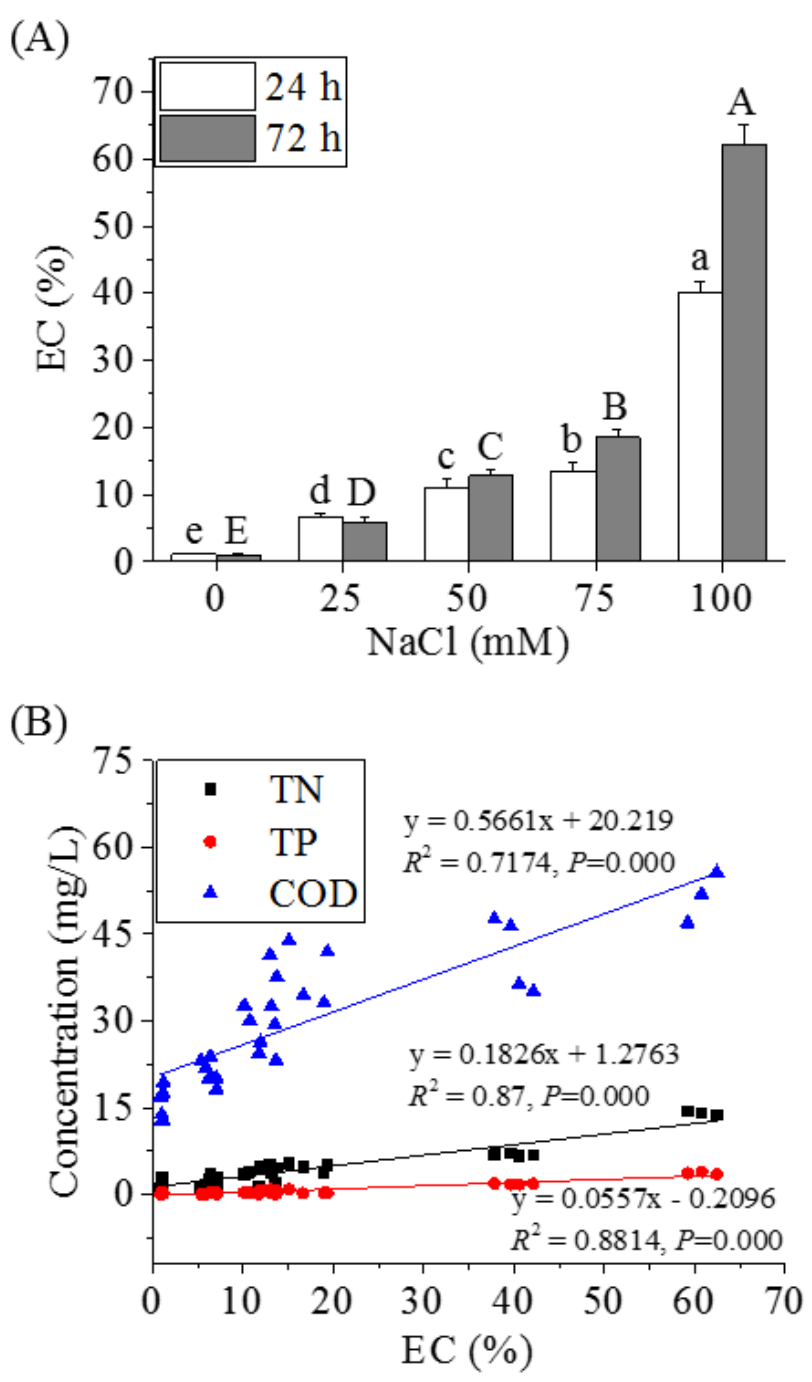

Fig. 6. Effect of $\mathrm{NaCl}$ on membrane permeability (A) and the relationship between membrane permeability and TP, TN, and COD, respectively (B). Means with different letters are significantly different $(P<0.05)$. Lowercase and uppercase letters are for the data of $24 \mathrm{~h}$ and $72 \mathrm{~h}$ of cultivation, respectively.

Plasma membrane may be the primary site of salt injury. Thus, it is important for plasma membrane to be less susceptible and maintain its low permeability under high-salt conditions (Mansour, 2013). Previous studies have shown that high salinity increased plant plasma membrane permeability. For example, Ismail (2003) found that $50 \mathrm{mM}$ salinity significantly increased the membrane permeability of maize and sorghum. Panda and Upadhyay (2004) observed the lipid peroxidation and loss of 
membrane integrity of duckweed (L. minor) under the stress of $\mathrm{NaCl}$ ranging from 50 to $200 \mathrm{mM}$. However, few studies on membrane permeability of duckweed that influenced by salt stress have been conducted. In the present work, membrane permeability was estimated indirectly with the electrolyte leakage, which consists of $\mathrm{K}^{+}$and so-called counterions $\left(\mathrm{Cl}^{-}, \mathrm{HPO}_{4}{ }^{2-}, \mathrm{NO}_{3}{ }^{-}\right.$, citrate $^{3-}$, and malate $\left.{ }^{2-}\right)$ (Demidchik et al., 2014). Some of these ions contributed to TN, TP, and COD in water. When the concentration of TN, TP, and COD (regardless of treatment) was plotted against EC, significant correlations between TN $\left(R^{2}=0.8700, P=0.000\right), \mathrm{TP}\left(R^{2}=0.8814, P=0.000\right)$, and COD $\left(R^{2}=\right.$ $0.7174, P=0.000)$ and EC were observed respectively (Fig. 6B). Total nitrogen, TP, and COD all increased linearly with increasing EC. Throughout the range of EC, COD showed greater variation than TN and TP. This result suggests that the injury of plasma membrane caused by salt stress may have more contribution to the generation of organic compounds (COD) than TN and TP.

\subsection{Implications for application in saline water}

According to our work, duckweed should be used carefully for purification water with high salinities. The tolerable salinities and suitable cultivation time (i.e., harvest frequency) need to be taken into consideration. Besides $\mathrm{N}$ and $\mathrm{P}$, the influence of salinity on the removal of other pollutants especially for organic compounds needs to be investigated. Recently, duckweed also showed the capacity of desalination of water by the uptake of dissolved salt (Balla et al., 2014), which confirmed duckweed as a promising candidate for saline water purification.

In addition to Lemna, duckweed family consists of several other genera including Spirodela, Landoltia, Wolffiella, and Wolffia (Crawford et al., 2006). According to previous studies, the tolerance of different species of duckweed to salt stress are quite 
different. Consequently, the performance of duckweed for $\mathrm{N}$ and $\mathrm{P}$ removal under salt stress may be different. Salt tolerance of duckweed has been improved by overexpression of the Arabidopsis photorespiratory pathway gene (AtAGT1) (Yang et al., 2013). These transgenic duckweed colonies are likely to be used to remove $\mathrm{N}$ and $\mathrm{P}$ under severe salt stress.

\section{Conclusions}

Our research showed that salt stress inhibited $\mathrm{N}$ and $\mathrm{P}$ removal by L. minor. Higher salt stress exerted more inhibitive effects on $\mathrm{N}$ and $\mathrm{P}$ removal. High-salt stress severely injured duckweed and reduced removal efficiencies of $\mathrm{N}$ and $\mathrm{P}$ even to negative levels. Longer cultivation time helped duckweed remove more $\mathrm{N}$ and $\mathrm{P}$ under low-salt stress and, conversely, induced more reduction in removal efficiencies under high-salt stress. Our results suggest that $L$. minor should be used to remove $\mathrm{N}$ and $\mathrm{P}$ from water with the salinities below $75 \mathrm{mM} \mathrm{NaCl}$ or equivalent salt stress.

\section{Acknowledgements}

This work was supported by the grants of National Natural Science Foundation of China (31370519), the Natural Science Foundation of Tianjin, China (14JCYBJC22700), and the National Science Foundation for Distinguished Young Scholars of China (41225014). We thank Prof. Yong Wang and Dr. Lin Yang for expert technical assistance with duckweed cultivation. We also thank Dr. Mia Rose Maltz at the University of California Riverside for language improvement.

\section{References}

American Public Health Association (APHA), American Water Works Association (AWWA), Water Environment Federation (WFF), 2007. Standard Methods for the Examination of Water and Wastewater. American Public Health Association, 
Washington, D.C.

Awad, A.S., Edwards, D.G., Campbell, L.C., 1990. Phosphorus enhancement of salt tolerance of tomato. Crop Sci. 30, 123-128.

Babel, S., Takizawa, S., Ozaki, H., 2002. Factors affecting seasonal variation of membrane filtration resistance caused by Chlorella algae. Water Res. 36, 1193-1202.

Bajji, M., Kinet, J.M., Lutts, S., 2002. The use of the electrolyte leakage method for assessing cell membrane stability as a water stress tolerance test in durum wheat. Plant Growth Regul. 36, 61-70.

Baker, J.H., Farr, I.S., 1987. Importance of dissolved organic matter produced by duckweed (Lemna minor) in a southern English river. Freshwater Biol. 17, 325-330.

Balla, D., Omar, M., Maassen, S., Hamidov, A., Khamidov, M., 2014. Efficiency of duckweed (Lemnaceae) for the desalination and treatment of agricultural drainage water in detention reservoirs. In: Mueller, L., et al. (Ed.), Novel Measurement and Assessment Tools for Monitoring and Management of Land and Water Resources in Agricultural Landscapes of Central Asia. Springer International Publishing Switzerland, Cham, pp. 423-440.

Bonomo, L., Pastorelli, G., Zambon, N., 1997. Advantages and limitations of duckweed-based wastewater treatment systems. Water Sci. Technol. 35, 239-246.

Boonyapookana, B., Upatham, E.S., Kruatrachue, M., Pokethitiyook, P., Singhakaew, S., 2002. Phytoaccumulation and phytotoxicity of cadmium and chromium in duckweed Wolffia globosa. Int. J. Phytoremediat. 4, 87-100.

Cedergreen, N., Madsen, T.V., 2002. Nitrogen uptake by the floating macrophyte Lemna minor. New Phytol. 155 (2), 285-292.

Cerezo, M., García-Agustín, P., Serna, M.D., Primo-Millo, E., 1997. Kinetics of nitrate 
uptake by Citrus seedlings and inhibitory effects of salinity. Plant Sci. 126, 105-112.

Chang, I.H., Cheng, K.T., Huang, P.C., Lin, Y.Y., Cheng, L.J., Cheng, T.S., 2012.

Oxidative stress in greater duckweed (Spirodela polyrhiza) caused by long-term $\mathrm{NaCl}$ exposure. Acta Physiol. Plant. 34, 1165-1176.

Cheng, T.S., Hung, M.J., Cheng, Y.I., Cheng, L.J., 2013. Calcium-induced proline accumulation contributes to amelioration of $\mathrm{NaCl}$ injury and expression of glutamine synthetase in greater duckweed (Spirodela polyrhiza L.). Aquat. Toxicol. 144-145, $265-274$.

Choi, T.S., Kang, E.J., Kim, J.H., Kim, K.Y., 2010. Effect of salinity on growth and nutrient uptake of Ulva pertusa (Chlorophyta) from an eelgrass bed. Algae 25, $17-26$.

Conley, D.J., Paerl, H.W., Howarth, R.W., Boesch, D.F., Seitzinger, S.P., Havens, K.E., Lancelot, C., Likens, G.E., 2009. Controlling eutrophication: nitrogen and phosphorus. Science 323, 1014-1015.

Crawford, D.J., Landolt, E.L.I.A.S., Les, D.H., Kimball, R.T., 2006. Speciation in duckweeds (Lemnaceae): phylogenetic and ecological inferences. Aliso 22, 229-240.

Demidchik, V., Straltsova, D., Medvedev, S.S., Pozhvanov, G.A., Sokolik, A., Yurin, V., 2014. Stress-induced electrolyte leakage: the role of $\mathrm{K}^{+}$-permeable channels and involvement in programmed cell death and metabolic adjustment. J. Exp. Bot. 65, $1259-1270$.

Dhote, S., Dixit, S., 2009. Water quality improvement through macrophytes - a review. Environ. Monit. Assess. 152, 149-153.

Hattink, J., Wolterbeek, H.T., de Goeij, J.J., 2001. Influence of salinity and eutrophication on bioaccumulation of ${ }^{99}$ technetium in duckweed. Environ. Toxicol. 
and Chem. 20, 996-1002.

Huang, F., Guo, Z., Xu, Z., 2007. Determined methods of chlorophyll from Lemma paucicostata. Exp. Technol. Manage. 24, 29-31, in Chinese.

Ingemarsson, B., Oscarson, P., Ugglas, M.A.F., Larsson, C.M., 1987. Nitrogen utilization in Lemna II. Studies of nitrate uptake using ${ }^{13} \mathrm{NO}_{3}{ }^{-}$. Plant Physiol. 85, $860-864$.

Ismail, A.M., 2003. Response of maize and sorghum to excess boron and salinity. Biol. Plantarum 47, 313-316.

Kaushal, S.S., 2016. Increased salinization decreases safe drinking water. Environ. Sci. Technol. 50, 2765-2766.

Körner, S., Vermaat, J.E., Veenstra, S., 2003. The capacity of duckweed to treat wastewater. J. Environ. Qual. 32, 1583-1590.

Leblebici, Z., Aksoy, A., Duman, F., 2011. Influence of salinity on the growth and heavy metal accumulation capacity of Spirodela polyrrhiza (Lemnaceae). Turk. J. Biol. 35, $215-220$.

Mansour, M.M.F., 2013. Plasma membrane permeability as an indicator of salt tolerance in plants. Biol. Plantarum, 57, 1-10.

Mbagwu, I.G., Adeniji, H.A., 1988. The nutritional content of duckweed (Lemna paucicostata Hegelm.) in the Kainji Lake area, Nigeria. Aquat. Bot. 29, 357-366.

Navarro, J.M., Botella, M.A., Cerdá, A., Martinez, V., 2001. Phosphorus uptake and translocation in salt-stressed melon plants. J. Plant Physiol. 158, 375-381.

Oukarroum, A., Bussotti, F., Goltsev, V., Kalaji, H.M., 2015. Correlation between reactive oxygen species production and photochemistry of photosystems I and II in Lemna gibba L. plants under salt stress. Environ. Exp. Bot. 109, 80-88. 
Panda, S.K., Upadhyay, R.K., 2004. Salt stress injury induces oxidative alterations and antioxidative defence in the roots of Lemna minor. Biol. Plantarum 48, 249-253.

Sikorski, Ł., Piotrowicz-Cieślak, A.I., Adomas, B., 2013. Phytotoxicity of sodium chloride towards common duckweed (Lemna minor L.) and yellow lupin (Lupinus luteus L.). Arch. Environ. Prot. 39, 117-128.

Soda, S., Ohchi, T., Piradee, J., Takai, Y., Ike, M., 2015. Duckweed biomass as a renewable biorefinery feedstock: ethanol and succinate production from Wolffia globosa. Biomass Bioenergy 813, 64-368.

Suppadit, T., 2011. Nutrient removal of effluent from quail farm through cultivation of Wolffia arrhiza. Bioresource Technol. 102, 7388-7392.

Szabó, S., Braun, M., Nagy, P., Balázsy, S., Reisinger, O., 2000. Decomposition of duckweed (Lemna gibba) under axenic and microbial conditions: flux of nutrients between litter water and sediment, the impact of leaching and microbial degradation. Hydrobiologia 434, 201-210.

Thomas, R.L., Sheard, R.W., Moyer, J.R., 1967. Comparison of conventional and automated procedures for nitrogen, phosphorus, and potassium analysis of plant material using a single digestion. Agro. J. 59, 240-243.

Twilley, R.R., Barko, J.W., 1990. The growth of submersed macrophytes under experimental salinity and light conditions. Estuaries 13, 311-321.

Wang, C., Zhang, S.H., Wang, P.F., Hou, J., Li, W., Zhang, W.J., 2008. Metabolic adaptations to ammonia-induced oxidative stress in leaves of the submerged macrophyte Vallisneria natans (Lour.) Hara. Aquat. Toxicol. 87, 88-98.

Wendeou, S.P.H., Aina, M.P., Crapper, M., Adjovi, E., Mama, D., 2013. Influence of salinity on duckweed growth and duckweed based wastewater treatment system. J. 
Water Resour. Prot. 5, 993-999.

Xu, J., Shen, G., 2011. Growing duckweed in swine wastewater for nutrient recovery and biomass production. Bioresource Technol. 102, 848-853.

Yan, B., Dai, Q., Liu, X., Huang, S., Wang, Z., 1996. Flooding-induced membrane damage, lipid oxidation and activated oxygen generation in corn leaves. Plant Soil $179,261-268$.

Yang, L., Han, H., Liu, M., Zuo, Z., Zhou, K., Lü, J., Zhu, Y., Bai, Y., Wang, Y., 2013. Overexpression of the Arabidopsis photorespiratory pathway gene, serine: glyoxylate aminotransferase (AtAGT1), leads to salt stress tolerance in transgenic duckweed (Lemna minor). Plant Cell Tiss. Organ Cult. 113, 407-416.

Yilmaz, D.D., 2007. Effects of salinity on growth and nickel accumulation capacity of Lemna gibba (Lemnaceae). J. Hazard. Mater. 147, 74-77.

Zirschky, J., Reed, S.C., 1988. The use of duckweed for wastewater treatment. J. WPCF $60,1253-1258$. 


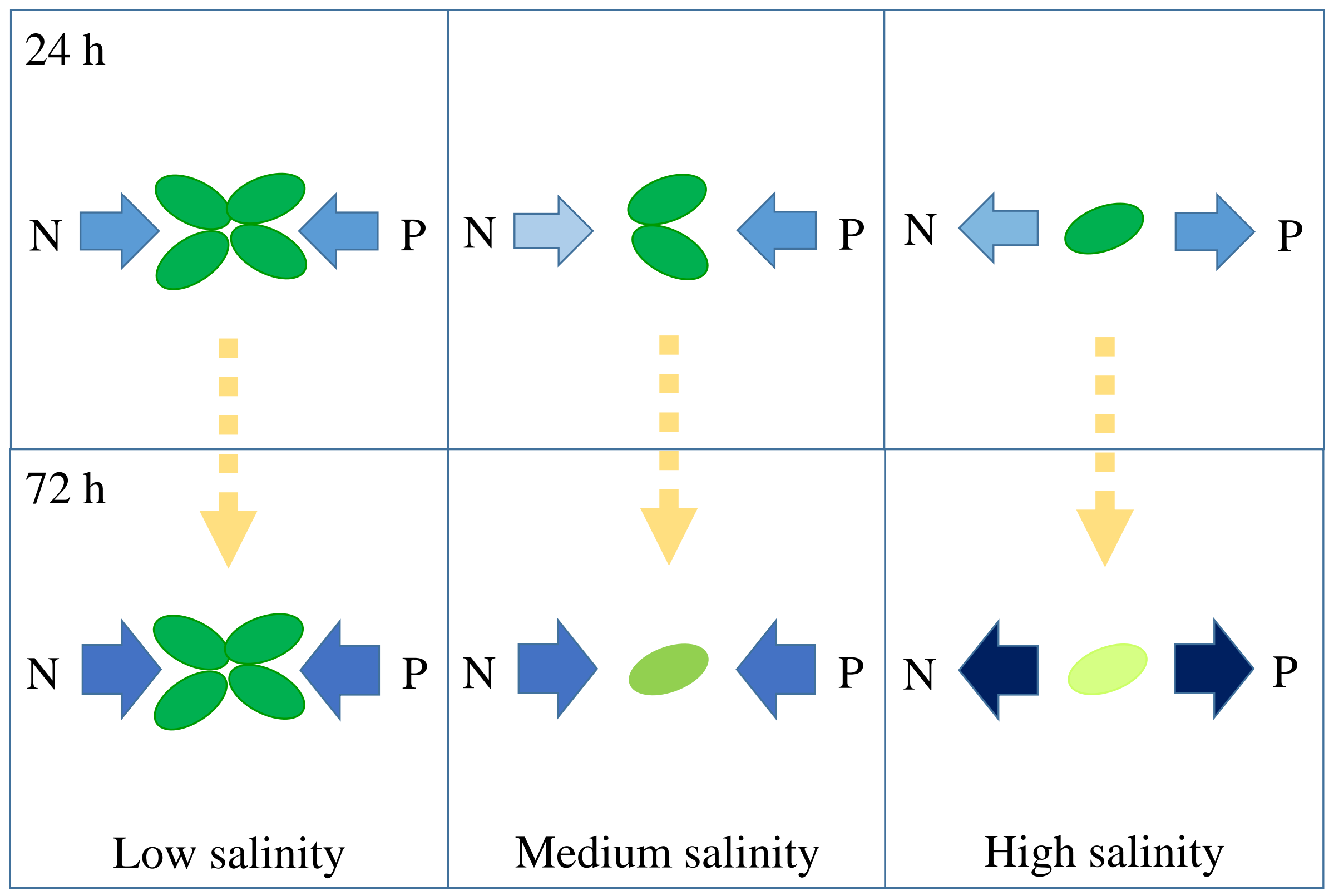

